\section{A Sociolinguistics Study of Conversational Swearing in Iran}

\author{
Mohammad Aliakbari (Corresponding author) \\ Dept. of English, Ilam University \\ PO Box 516, Ilam 69315, Iran
}

Tel: 98-918-341-3283Ｅ-mail: maliakbari@hotmail.com

Zahra Heidarizadi

Dept. of English, Ilam University

PO Box 516, Ilam 69315, Iran

Tel: 98-918-844-1912Ｅ-mail: zheidarizadi@gmail.com

\author{
Elham Mahjub \\ Dept. of English, Ilam University \\ PO Box 516, Ilam 69315, Iran \\ Tel: 98-917-337-5068Ｅ-mail: mahjub.e@gmail.com
}

Received: March 12, 2013 Accepted: March 27, 2013 Published: June 24, 2013

doi:10.5296/ijl.v5i3.3899 URL: http://dx.doi.org/10.5296/ijl.v5i3.3899

\begin{abstract}
As a lingual feature, 'swearing' has been presented since long among different cultures with various conceptual and linguistic realizations. In this study an attempt has been made to represent a comprehensive taxonomy of swear expressions in contemporary Persian language. Data were collected from the actual performance of speakers in their daily conversations and undertakings. The corpus yielded itself to a taxonomy including 15 categories and 7 subcategories. From among more than 250 natural instances of swear expressions about 45 instances have been provided in the form of sentences in the body of the article and at a table in
\end{abstract}




\section{Macrothink}

International Journal of Linguistics

ISSN 1948-5425

2013, Vol. 5, No. 3

the Appendix. The research findings made it clear that religious oaths, swearing by holy times, foods and meals, parts of body, and family members were respectively the top most frequent categories of Persian swear expressions in the context of research.

Keywords: Swearing, Speech acts, Conversational strategy, Swearing taxonomy, Persian swearing 


\section{Introduction}

As an old communicative phenomenon, swearing has been a frequent speech act adopted in daily conversation as well as formal ceremonies in Iran. The loan word "Qasam" from Arabic and the old Avestan word "Sougand" are the equivalent terms for swearing in contemporary Persian language.

As Abdel-Jawad (2000) notes Qasam, a synonym of yamiin or 'oath' is the speech act by which an individual necessitates him/herself to do or not to do a particular physical or juridical act, by referring the name of God or one of the sacred powers. He continues that based on their domains, oaths can be classified into three groups: " judiciary oaths which are formally taken in the court of law; loyalty, constitutional or office oaths and pledges taken by senior officials when assuming office; and finally extra judiciary or conversational swearing uttered by people rather routinely in their daily interactions and dealings" (p.218).

In different eras, swearing has oriented toward different forms depending on the poets', writers', and critics' interests. As a result in one time the religious swearing has been prevalent and in another time the emotional swearing and still in the next time the dirty swearing expressions have been thrived. Today, swearing is a commonplace phenomenon among Iranian people to the extent that they often swear quit frequently without much attention being devoted to the fact that what they say is a swear expression.

From another perspective, swearing is a culturally loaded act. Iranians often accompany their wording with religious oaths to show its truth, simply because the holy oaths work as an emphasizer to show the legitimacy of one's saying. Being stimulated by the frequency and importance of the swearing in the Iranian Muslims' daily discourse and the paucity of linguistic studies on this kind of speech acts, the present study attempts to provide a relatively comprehensive index of this speech act among Persian speakers in Iran. Put it in different words, the present study is to investigate the conversational swearing (CS henceforth) speech act that is used as a communicative strategy in Iran. It, thus, intends to seek answer for the following question: What do Iranian speakers commonly swear by?

\section{Review of the Related Literature}

Swearing can be defined with regard to its two different meanings. The first type according to Simpson and Edmund (2010) occurs to confirm the correctness of ones' saying by adding a linguistic formula (which works as a formal desire to God or a divine power) to one's saying. The other application, as noted by Strawson, (1986:7) is broader than the first one. It not only includes the act of oath taking but that of deploying taboo, bad, and profane language for disgracing others.

Though a number of studies have been done on swearing on its second sense, (e.g. Taylor, 1975; Strawson, 1986; Gray, 1993; Stein-Wilkeshuis, 2002; McEnery and Zhonghua, 2004; Rassin and Muris, 2004; Lyona and Doradob, 2008; Jay, 2009), very few research works have been conducted on its first meaning (Kiani, 1991; Abd el-Jawad, 2000; Mansouri, 2011). 
As for swearing in the first sense, MC Enery (2004) considered swearing as a part of everyday language use and investigated swear words in English from demographic point of view (age, gender, and social class), and textual features (register, publication medium, and domain). Rassin and Muris (2005) also considered swearing as a considerable societal phenomenon which is forbidden under some conditions and is quite common on others. Their research findings showed that the most reason of swearing among their population was the expression of negative emotions. Besides, while swearing was associated with various other forms of aggression, it was not correlated with life satisfaction.

On the other hand, Abd el-Jawad (2000) investigated the variety of second application of swearing in Arabic. To present a general picture of CS in Jordan, he has brought a corpus of oaths exchanged by interlocutors in real-life contexts under analysis. The findings of his study made it clear that swearing has exhibited an exclusive degree of variation in form, usage and function, and that it has served a wide range of communicative functions. Additionally, it was suggested that oaths can be studied as a cultural index of a given community, since they reflected the cultural patterns, values, and themes that were dominant in Jordan. He further, maintained that they might also be studied in a strict linguistic setting, for example as moves to preface and modify speech act.

Mansouri (2011) in his Master Thesis studied swearing in Persian with a two-fold purpose; giving a typology of the lexical categories of oaths used by Kurdish speakers in Ilam province and exploring why such categories are used and the extent to which they are influenced by age, gender, education, place of living, and job. The findings of his study confirmed the existence of a strong relationship between the type and frequency of oath words and the variables of age, gender, level of education, employment, and place of living. His study, further, revealed that religious, death, and family members' oaths were the most frequent oath words, respectively, taken by the respondents to indicate and maintain trust in their interactions.

Kiani (1991) in a different attempt has brought under analysis different reasons of swearing and asserted that people swear to reach 21 targets in their mind. The major relevant functions include: 1). Emphasize a subject, 2). Prove the guiltiness and exoneration (it is seen more in swearing formula), 3). Make a speech believable, 4). Prove a claim, 5). Assure others, 6). Warn and threat others, 7). Excite and encourage others, 8). Chastise and correct ones, 9). Glorify ones, 10). Gain favor or access, 11). Negate a subject, 12). Complain and describe the adventures, and 13). Insist and urge for proving their claim.

\section{The Study}

Swearing by holy things and the dear ones has long been prevalent throughout the history of Iran. Pre-Islamic Iranians used to swear by wine, musical instruments, and the pulchritude of their lovers, but the Holy Quran changed the direction of swearing to substitute the religious concepts. The major intent in conducting the current research was to provide a sort of encyclopedic index of what Iranian speakers swear by.

To collect data, a wide range of people with different gender, age, social status, and 
educational background in their actual performance of daily conversations and undertakings were encountered. The proper corpus was recorded during a period of three months. After eliminating the repeated swearings, it was possible to compile a corpus of data including more than 250 instances. Scrutinizing the Iranian speakers prevalent swearing in daily conversations, the corpus was classified into 15 categories. In the sections that follow examples of swearing for each category along with necessary explanation are presented. Due to the limitation of space, 75 instances have been provided in the form of sentences in the text and the rest are at Table1 or in the Appendix.

\subsection{Allah}

Iranian speakers regardless of their age, gender and educational level generally swear by Almighty Allah, His great names, purity, magnificence, and created beings. They swear by both the Persian and Arabic name of God: باله خدا، و الله، بالله، والله و باله all of them mean by God;

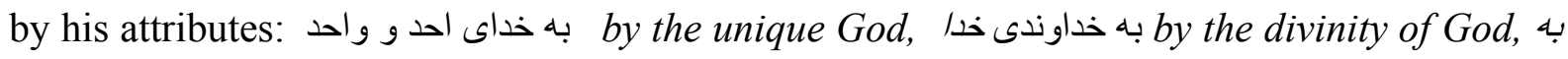

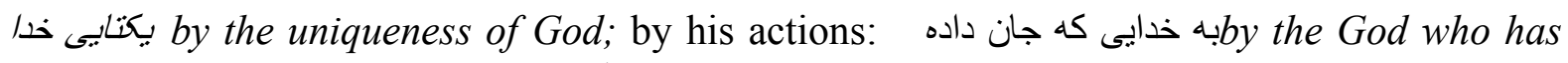
created the soul به كرداننده زمين و آسمان خدا : خاحب روز و شب شاهده ،خدا كواهه، خدا وكيله repeatedly seen that swearing has been made by any of the 1001 Excellent Names of Allah, e.g. Aziz, Jabber, Samad, Rahman, etc. respectively Mean 'Almighty', 'Compeller', 'Not needy', and 'Kind'. The following examples can further clarify the issue:

1. By Allah, I'm busy. به خدا، سرم شلو غه.

2. By the uniqueness of Allah, I will do my promise. بك يكتايى خدا، سر قولم مى مانم.

3. By the witness of Allah, I'm not lying. خدا شاهده، دروغ نمى كويم

4. By the achromatic God, her treason is not forgivable. به يزدان يكرنك، خيانت او قابل بخشش نيست

5. By the God who manages the earth and the sky, I can no longer continue with this condition. به خدايى كه كرداننده آسمون و زمين است، ديكه نمى تونم با اين شر ايط ادامه بدم

\subsection{The Holly Book}

Swearing by the Holly Quran is taken place in different ways, accompanying the term Quran by panegyric adjectives: به قرآن مجيد by the great Book ، به قرآن كريم by the generous Book; attributing Quran to the prophet Mohammad who is it's bringer: به قرآن محمد 'by the Quran of Mohammad, به قر آن سينه محمد by the Quran in the heart of Mohammad; accompanying Quran by color adjectives: به قرآن زرد

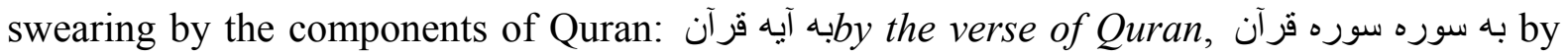

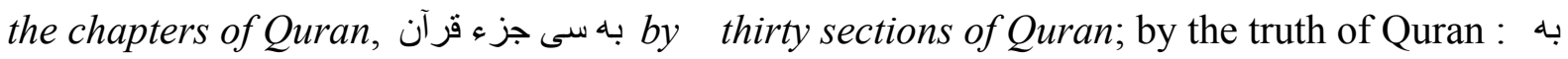

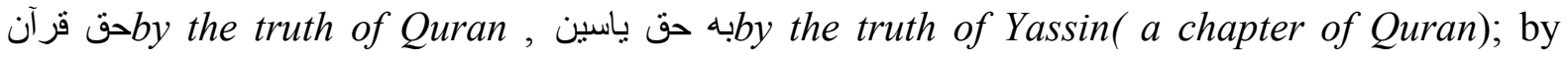
referring to the holly Book:به كلام خدا،به /ين كتاب مقدس، به /ين قرآن that respectively mean by Quran, by this Holly Book, by these words/verses of Allah. The following true examples may better clarify the point: 
6. By the verse of Quran, I studied the subject. به آيه قرآن، درس را خو اندم.

7. By the truth of Quran, I painted the door. به حق قرآن، در را رنعى زدم.

8. By the great Book, I cleaned the table. به قرآن مجيد، ميز را تميز كردم.

9. By the Quran of Mohammad, I will kill you. به قرآن محمد، مى كثمت

10. By the truth of Yassin, I could not study because my mother was ill.

$$
\text { به حق ياسين، جون مادرم مريض بود نتونستم درس بخونم. }
$$

\subsection{The Prophets}

Following the belief for the existence of 124000 prophets, Iranians mostly swear by the last

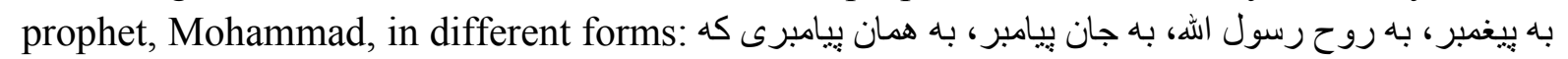
زيارت كردى، به محمد به رسول الله visited، by the life of the Prophet, by the soul of the Messenger of Allah, by the Prophet, by the Mohammad، by the Messenger of Allah. Whenever the general term prophet is used, Shia presupposes it as the Prophet Mohammad.

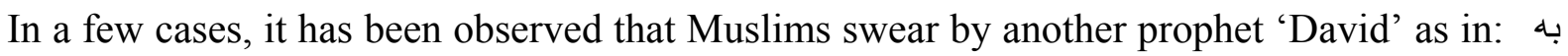

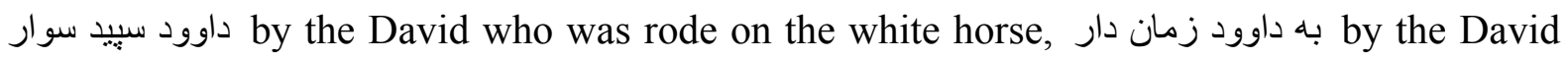
who is time owner. The following examples also deserve notice:

11. By the majesty Mohammad, I can't do what you say.

$$
\text { به حضرت محمد، نمى نو انم آنجه شما مى كوييد را انجام دهم. }
$$

12. By the Davied who is time owner, I shall go. به داوود زمان دار، بايد بروم.

13. By the dignity of the prophet you have visited, I promise to help you.

$$
\text { به همون بيغمبرى كه زيارت كردى، قول ميدم به نو كمى كنم }
$$

14. By the soul of the Messenger of Allah, I love your son as much as mine.

$$
\text { به روح رسول الله ، يِر تو را مثل بِر خودم دوست دارم. }
$$

15. By the life of Prophet, all of us are aware of your good faith.

$$
\text { به جان بيامبر، همه ما از نيت خوب شما باخبريم. }
$$

\subsection{Imams}

Although Iranian speakers believe in all of the 12 Imams, they mostly swear by few of them like Imam Ali, Hassan, Hossein, Sajad, Reza, Mousa Alkazim, and Mahdi. Some of these tendencies has a root in people's belief; for instance, imam Ali has been attended to since he is the first and the most justice, Imam Hossein is the Iranian's bridegroom and was martyred oppressively, Imam Reza is the most alone one, and Mahdi is the last one anticipated to be the starter of a new monotheism era.

Also the Imams' and prophets' grandchildren, Imamzadehes, like Shahcheragh, Shah Ahmad, 
Ali Saleh, Shahzadeh Ahmad and others are saint enough to swear by, mostly by the people living next to their shines. In addition, Imam Hossein's brother, Abolfazl, is one of the main figures sworn by in Iran. People widely believe in him because of his dignity, courage, and faith. Examples 16 to 20 also explain more:

16. By Imam Reza, I don't do so. به امام رضا، من اين كارو نمى كنم.

17. By Imamzadeh Saleh, I will go. به امامز اده صالح، من مى روم

18. By the eighth Imam (Reza), what is between you and Amir is only a misunderstanding. به امام هشتم، آنجه بين شماو امير اتفاق افتاده فقط يك سوء تفاهمهـ..

19. By Abolfazl, I will defend my fatherland till my death time.

$$
\text { به ابو الفضل، تا لحظه مركم از وطنم دفاع مى كنم. }
$$

20. By the thirsty lips of Hossein, I never accept your injustice.

$$
\text { به لبان تشنه امام حسين، بى عدالتى شما را قبول ندارم. }
$$

\subsection{The Chaste Women}

Like the Imams and Prophets, there are several chaste women who are considered saint enough to swear by; most of whom are the sisters, mother, daughter, or wife of Imams and Prophets. Like: حضرت فاطمه her majesty Fatemeh ( the daughter of Prophet Mohammad, the wife of Imam Ali, and the mother of Imams Hassan, Hossein), her majesty Zeinab her majesty Massomeh, حضرت خديجه her majesty Khadijeh( the wife of Prophet Mohammad),حضرت رقديه her majesty Roghayyeh ( the daughter of Imam Hossein), her majesty Maryam ( Saint Mary, the mother of the Prophet of Christianity 'Jesus'), and ام البنين the Ommolbanin( the mother of Imamzadeh Abolfazl). The following examples will adequately convey the matter.

21. By her majesty Zeinab, you are lying. به حضرت زينب، دروغ مى گويى.

22. By her majesty Ommolbanin, I won't forgive you. به ام البنين نمي بخشمت

23. By her majesty Zahra, I promise to do my best.

$$
\text { به حضرت ز هر ا، قول مي دهم نهايت تلاشم را بكنم. }
$$

24. By her Majesty Maryam, Ali is the brother of Mahdi.

$$
\text { به حضرت مريم، على بر ادر مهدى است. }
$$

25. By her majesty Khadijeh, Sara could not remember the gist of Mari’s saying.

$$
\text { به حضرت خديجه، سار ا نتونست موضوع اصلى كفته مريم را به ياد آورد. }
$$

\subsection{Important People}

There are always the enormous figures whose existence have had an influence upon the politic, economy, literature, or science, of their homeland, say, Imam Khomeini ( the late leader of Islamic Republic of Iran ), leader Khameneie, Sayed Ahmadi, and Sayed Hassan 


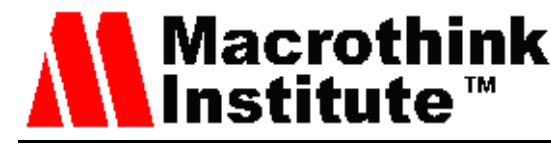

Sayed who are descendants of holy Imams are sworn by frequently. The following examples may illustrate the point.

26. By the pure soul of Khomeini, I haven't broken the glass.

$$
\text { به روح پِاك خمينى، من ليوان را نشكستم. }
$$

27. By the majesty Khameneie, I will tell you the truth.

$$
\text { به حضرت خامنه اي حقيقت را بهت مي كم. }
$$

28. By the great grandfather of Sayed Hassan Sayed, I made it by myself.

$$
\text { باه جد سيد حسن سيد ، من خودم تنهايي اونو ساختم. }
$$

29. By the great grandfather of Sayed Ahmadi, Farhad was not at home.

$$
\text { به جد سيد احمدى، فر هاد خانه نبود. }
$$

30. By Imam Khomeini the Great, Amir did not give Reza the birthday gift.

$$
\text { به خمينى كبير ، امير به رضا هديه تولد نداد. }
$$

\subsection{Family Members}

It was observed that the love, feeling, affection, and sincerity among the family members make the individuals to swear by the life, death, head, and honor of each other even when the sworn person is absent or departed. Swearing by the life of children is very common as well. Iranian children swear also by the life of their grandmothers, grandfathers, aunts, and uncles. The following examples can be considered for more clarification:

31. By the soul of my grandfather, I tell the truth. به روح بابا بزركم، راست مى كويم.

32. By the life of my mother, I am very tired. به جون مامانم، خيلى خسته ام.

33. By the youth of my brother who is in trip, I didn't annoy her.

$$
\text { به جو انى داداشم كه در سفره، من اذيتش نكردم. }
$$

34. By the death of my son, Akbar has seen Ahmad's brother in the party.

$$
\text { به مرك يسرم، اكبر برادر احمد را در مهمانى ديده است. }
$$

35. Daddy! By the life of my uncle, I did not break it. بابا! به جان عموم، من نشكستمش.

\subsection{Parts or Attributes of the Body}

In our search for the general index of swearing, we noticed that parts of body like neck, mustache, beard, hair, and eyes are the objects of so many swearing since they are considered as the symbol of manhood, greatness, chastity, etc, like: به مويت قسم by your hair بهر

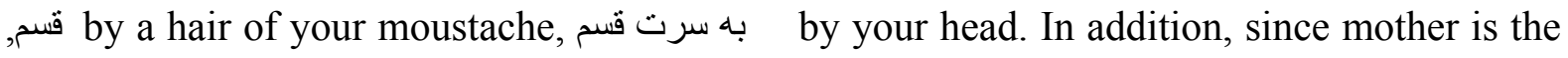
symbol of purity, generosity, and kindness, her hair, milk, and pure skirt are the objects of by the tress of my mother. Besides, in the memory of the soldiers who endangered their life to save their nation, there are the reminiscence of their 
comrades in arms so that in their daily conversations soldiers swear by the blood of their comrades e.g. به خون همرزمانم by the blood of my comrades in arms, or به خون هر جه شهيد by the blood of every martyr. The following examples elucidate the issue:

36. By your hair, I will bring together your money. به مويت قنم يول را جور مى كنم.

37. By the milk of my mother, it was not my mistake. به شير مادرم، من مقصر نبودم.

38. By the soul of my comrades in arms, I will defend Islam in my long life.

$$
\text { به خون همرزمانم، تمام طول عمرم از اسلام دفاع مى كنم. }
$$

39. Sadaf! By your eyes, I will take you to park. صدف! به جشمات قسم، مى برمت پِارك.

400. Father! By your white beard, I will find the thief.

$$
\text { بابا! به ريش سفيدت قسم، دزد را يِيدا مى كنم. }
$$

\subsection{Holy Places}

Due to religious orientation, Persian speakers occasionally swear by holy places like the house of God, mosques, and the holy shrine of the Prophet and Imams. These sacred places are always the center of attention for people's swearing, though most of them are not in their

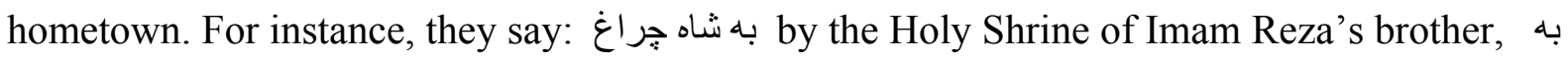
همان كعبه كه بوسيدم by the Ka'abe that I kissed, به زمين قيامت by the land of Resurrection. In fact this practice can extend to any mosque or any other place of religious significance.

Consider the given examples below:

41. By the Ka'abe, I tell the truth. به كعبه قسم، من راستشو مى كويم.

42. By the land of Resurrection, he is not guilty. به زمين قيامت قسم، او بى كناه است.

43. By the plain of Karbala, I shall see him before my trip.

$$
\text { به دشت كربلا، من بايد قبل از سفرم او را ببينم. }
$$

44. By the house of God, all of the sixth employees have been retired.

$$
\text { به خانه خدا، همه شش كارمند بازنشست شده اند. }
$$

45. By the six-angle tomb of Hossein, we spoke about our project.

$$
\text { به قبر شش كَّه امام حسين، ما در مورد طرحمان حرف زديم. }
$$

\subsection{Holy Times}

In Muslims yearly calendar, there are sanctity times to swear by. People swear by the new year, the month of Ramazan, Sha'aban, Moharram, the days of Prophet's or Imams' birthdays, the holy days of Fetr, Qorban, the death day, the Resurrection day, and the hours ' of sunrise, sunset, Azan, ( the time of calling for praying ), etc. Follow the examples for more instances:

46. By this time of calling for praying, I have no information about it. 
47. By this sunset of Morteza Ali, let me alone. تو را به اين غروب مرتضى على، تنهام بذار.

48. By this Friday night, I saw her in my dream with shiny face.

$$
\text { به اين شب جمعه، او را با صورت نور انى در خواب ديدم. }
$$

49. By this dark night, you will be regretted. به اين شب تار، يُشيمان مى شوى.

50. By this yellow sunset, I will defeat the problems.

$$
\text { به اين غروب زرد، من از عهده مشكلات بر مى آيم. }
$$

\subsection{All Allah's Creatures and Creation}

In His holy book Quran, God has sweared by almost any creature created by Him, say, به تبن

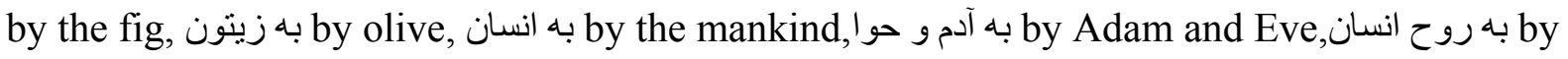

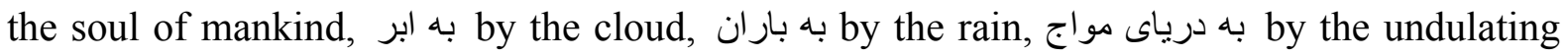
sea, به به قلم ابه by the py the pen, به خلقت كائنات by the creation of beings, etc. Though people here access to a wide range of Quranic swears, they only use a limited range of them

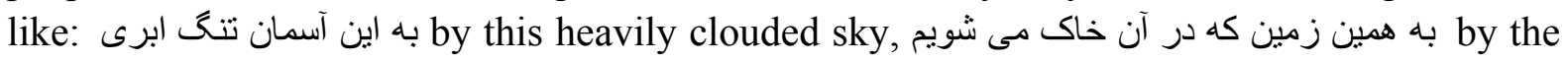
earth in which we are to be buried, به اين خورشيد by this shinny sun. Follow the examples:

51. By the bright sun, I won't speak with you hereafter.

$$
\text { به خورشيد تابناك، از اين به بعد باهات حرف نمى زنم. }
$$

52. By the heavily clouded sky, we had not high income from our last year's product.

$$
\text { به اين آسمان تنى ابري، از محصول پيارسال در آمد زيادي عايد ما نشد. }
$$

53. By the blue sky, domestic fowls were at rain, I made a fowl-run for them.

$$
\text { به آسمان آبى قسم، مرغ و خروس ها در بار ان بودند، من يك مر غدانى بر ایى آنها ساختم. }
$$

54. By the yellowness of the sunset, we bought this car twice as much as its usual price.

$$
\text { به زردى غروب، ما ماشين را دو بر ابر قيمت عاديش خريديم. }
$$

55. By this rain, the human kind is always ungrateful to his God.

$$
\text { به اين بار ان قسم، انسان هميشه نسبت به يروردكارش ناسِياس است. }
$$

\subsection{Foods and Meals}

People use articles of food as swear words especially when they gather around a dining table for a meal and discussing a matter. The salt, liquids, bread, and votives can be put in this category. The following examples help a better understanding:

56. By this salt, I will remain faithful to you. به حق اين نمك، من به شما وفادار خو اهم ماند.

57. By the Imam Hosseins' juice, I promise to improve my behavior.

$$
\text { به شربت امام حسين، قول ميدم رفتارم را عوض كنم. }
$$




\section{IIMacrothink}

58. By the truth of this votive food, I agree with this trade.

$$
\text { به حق اين نذرى، من با اين معامله مو افقم. }
$$

59. By the truth of this blessing, we waited two hours for the train.

$$
\text { به حق اين بركت، ما دو ساعت منتظر قطار بوديم. }
$$

60. By these seeds of pomegranate, Akbar went to the trip.

$$
\text { به اين دانه هاى انار قسم، اكبر به سفر رفت. }
$$

\subsection{Moral Values}

In every culture there are some moral and respectable values that people admire. Such concepts are always objects of swearing among people in Iran. Swearing can take place just by these values themselves: به قول درست by the right promise; by attributing these values to

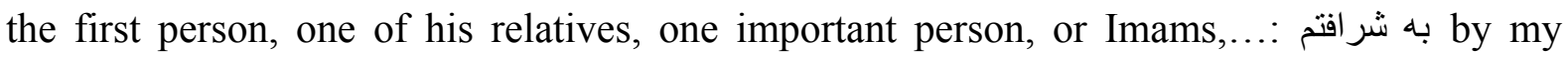
gentility, به شر افت يدرم by my father's gentility, به شر افت امام رضا by Imam Reza's gentility; or

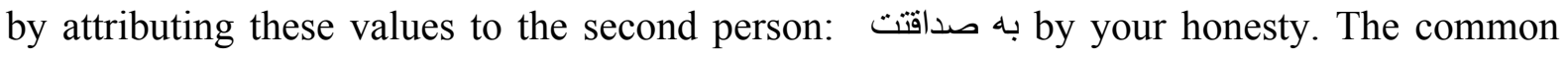
swears of this category have been shown in examples that follow:

61. By the dignity of brotherhood, I will help you as far as I can.

$$
\text { به جان بر ادرى، نا آنجايى كه امكان داشته باثد به تو كمك خو اهم كرد. }
$$

62. By the essence of friendship, I will remain faithful to you to eternity.

$$
\text { به رفاقت قسم، تا ابد به تو وفادار خو اهم بود. }
$$

63. By your dearness, I invoke your health and success.

$$
\text { به عزيزيت قسم، من سلامني و موفقييتت را آرزومندم. }
$$

64. By my generosity, I will protect you against his threats.

$$
\text { به مردانكى ام قسم، من از شما در مقابل او حمايت مى كنم. }
$$

65. By our truthfulness, Ali was saved from a certain death.

$$
\text { به صداقتمان قسم ، على از مرك حتمى نجات يافت. }
$$

\subsection{Sanctities}

In addition to moral values which are abstract ideals in the mind of the swearers, the sanctities are concrete or holy objects swearing by which is common. The common formulas of them are: به تمام مقدسات عالم by all of the world sanctities, به به قبر بر ادرم by the tomb of my brother, به سكه درست by the accurate coin. The examples below are notable for this category.

66. By my religion, no one can answer the questions.

$$
\text { به دينم، هيجِكس نمى نو اند به سوالات بِاسخ دهد. }
$$

67. By the dead in the grave, I have no idea. بك خفتحان خاك، من هيج نظرى ندارم 
68. By the Azan (the time of calling for praying) of Mohammad, I did not disappoint Sara.

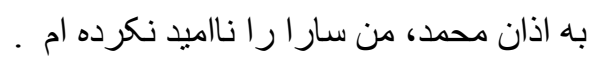

69. By the martyr's tomb, everything has frozen. به قبر هر جى شهيده، همه جيز يخ بسته.

70. By my fortune, this plan cannot meet our needs.

$$
\text { باه بختم، اين نقتشه نمى نو اند نياز هاى ما را بر آورده كند. }
$$

\subsection{Conditional Swearing}

This category of swearing is often performed when a person wants to show his serious intention. In this category, the swearer wishes a condition to take place if s/he does not do

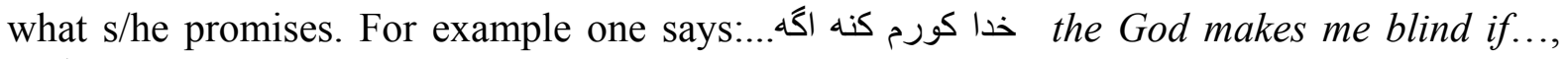
عزيزم را كفن كنى اكه... you enshroud my darling if I .... More examples are followed for clarifying the issue.

71. The Quran breaks my back, if I deceive you. قرآن به كمرم بزنه اخه كولت بزنم

72. I die, if I believe the rumors about you. اين تن بميره اكه شايعه هاى در مورد تو را باور كنم

73. You enshroud my darling, if I let Ahmad to come with you.

$$
\text { عزيزم را كفن كنى اكر بذارم احمد با شما بياد. }
$$

74. The God makes me blind, if I sign the contract. خدا كورم كنه اكه قرداد را امضا كنم.

75. This body dies, if I do not help you. اين تن بميره اگه كمكت نكنم

\section{Discussion and Conclusion}

In this study especial attention has been paid to present a relatively comprehensive taxonomy of swearing speech act by Persian speakers in Iran. Developing 15 broad categories, 7 narrower subcategories, and more than 250 natural instances of swear words, we can strongly claim for the richness of Persian language regarding this speech act. Put it in nutshell, the above mentioned categories or classes of what Persian speakers swear by are schematically presented in Table 1 bellow.

Table 1. A schematic preview of Iranians' swearings

\begin{tabular}{|l|l|}
\hline God & $\begin{array}{l}\text { By God, by the unique God, by the divinity of God, by the uniqueness of } \\
\text { God, by the God who has created the soul ، by the God who manages the } \\
\text { earth and the sky by the God who is the master of day and night, by the } \\
\text { witness of God. }\end{array}$ \\
\hline Quran & $\begin{array}{l}\text { By the great book, by the generous book, by the Quran of Mohammad, } \\
\text { by the Quran in the breast of Mohammad, by the yellow Quran, by the } \\
\text { green cover Quran, by the verse of Quran, by the chapters of Quran, by } \\
\text { thirty sections of Quran, by the truthness of Quran, by the truthess of } \\
\text { Yassin (a chapter of Quran), by Quran, by this Holly Book, by these } \\
\text { words/verses of Allah. }\end{array}$ \\
\hline
\end{tabular}




\begin{tabular}{|c|c|}
\hline Prophets & $\begin{array}{l}\text { By the dignity of the Prophet you have visited, by the life of the prophet, } \\
\text { by the soul of the messenger of Allah, by the prophet, by Mohammad, by } \\
\text { the messenger of Allah, By the David who is time owner. }\end{array}$ \\
\hline $\begin{array}{l}\text { Imams and } \\
\text { Innocents }\end{array}$ & $\begin{array}{l}\text { By Ali, Hassan, Hossein, Sajad, Mousa Alkazim, Reza, and Mahdi. } \\
\text { Shahcheragh, Shah Ahmad, Ali-Saleh, Shahzadeh Ahmad, Abolfazl. }\end{array}$ \\
\hline $\begin{array}{l}\text { Chaste } \\
\text { women }\end{array}$ & $\begin{array}{l}\text { By her majesty Fatemeh, her majesty Khadijeh, her majesty Roghayyeh, } \\
\text { her majesty Maryam, her majesty Massoomeh, her majesty Zeinab, and } \\
\text { the Ommolbanin. }\end{array}$ \\
\hline $\begin{array}{l}\text { Important } \\
\text { people }\end{array}$ & $\begin{array}{l}\text { By Imam Khomeini the Great, the majesty Khameneie, the great } \\
\text { grandfather of Sayed Hassan Sayed, and the great grandfather of sayed } \\
\text { Ahmadi. }\end{array}$ \\
\hline $\begin{array}{l}\text { Family } \\
\text { members }\end{array}$ & $\begin{array}{l}\text { By the soul of my grandfather, by the life of my mother, By the youth of } \\
\text { my brother. }\end{array}$ \\
\hline $\begin{array}{l}\text { Parts of the } \\
\text { body }\end{array}$ & $\begin{array}{l}\text { By your hair, by the hair of your moustache, by your head,by the tress of } \\
\text { my mother, by the blood of my comrades in arms, by the blood of every } \\
\text { martyr, by the milk of my mother, by your eyes. }\end{array}$ \\
\hline Holy & $\begin{array}{l}\text { By the Holy Shrine of Imam Reza's brother, by the Ka'abe, by the land of } \\
\text { Resurrection. }\end{array}$ \\
\hline Holy times & $\begin{array}{l}\text { By the new year, the month of Ramazan, the month of Sha'aban, the } \\
\text { month of Moharram, the days of Prophet's or Imams' birthdays, the holy } \\
\text { days of Fetr, Qorban, the death day, the resurrection day, the hours ' of } \\
\text { sunrise, sunset, Azan or the time of Calling for praying. }\end{array}$ \\
\hline Creatures & $\begin{array}{l}\text { By the fig, by olive, by the mankind, by the undulating sea, by this } \\
\text { heavily clouded sky, by the earth in which we are to be buried, by this } \\
\text { shinny sun, by this rain. }\end{array}$ \\
\hline $\begin{array}{l}\text { Foods and } \\
\text { meals }\end{array}$ & $\begin{array}{l}\text { By this salt, by Imam Hosseins' juice, by the truthness of this votive } \\
\text { food, by the fruits of paradise, by the countless seeds, by the salt. }\end{array}$ \\
\hline Moral values & $\begin{array}{l}\text { By the right promise, by my gentility, by my father's gentility, by Imam } \\
\text { Reza's gentility, by your honesty, by the power of brotherhood, by the } \\
\text { essence of friendship, by your dearness. }\end{array}$ \\
\hline Sanctities & $\begin{array}{l}\text { By all of the world sanctities, by the tomb of my brother, by the accurate } \\
\text { coin, by my religion, by the dead in the dust. }\end{array}$ \\
\hline $\begin{array}{l}\text { Conditional } \\
\text { swearing }\end{array}$ & $\begin{array}{l}\text { The God make me blind, if..., you enshroud my darling, if ...., the } \\
\text { Quran breaks my back, if...., I die, if...... }\end{array}$ \\
\hline
\end{tabular}

However, With respect to the dynamic characteristic of all languages in general and Persian language in particular swear words have taken different forms and the scope of their richness may changes. Another important point which is worth mentioning is the great degree of similarities between the taxonomies provided by Abd el Jawad (2000) in Jordan, Mansury (2011) among Iranian Kurdish speakers, and the types of swearing presented here. Though these studies report research findings from Arabic, Kurdish, and Persian languages 
respectively, their similar religious environment may account for the similarity observed. Therefore, it is right to claim that swearing is originally and mostly religious in nature. From the presented taxonomy it is clear that after religious swearing which form a significant part of swear words, swearing by holy times, foods and meals, parts of body, and family members are more frequent respectively.

It deserves notice that swearing as a linguistic performance has a distinctive role in introducing the culture of the swearers by referring to the moral values, sanctities, religion, family relations, and other attributes in the form of swear. Besides, the cultural and lingual relations of the speakers in different countries may expand the lexicon of the target language and brings about a type of loan words. The presence of Arabic loan words among Iranian swear words ( و الله، بالله، والله و بالله all of them mean by God, به غروب الغاربين by the sunset of those who have been departed from their hometown, به غريب الغربا by the most alone one

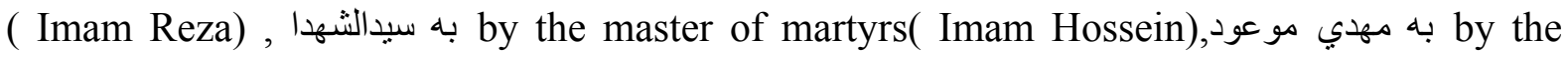
promised Mahdi, به صاحب الزمان by the owner of time( Imam Mahdi)) show the footprints of cultural and lingual relations of one or both sides of an interaction.

Moreover, it should be noted that this study has only addressed the question of what do Iranian speakers commonly swear by, while, there is still a vast number of questions left unanswered. They can be the subjects of further research. Additionally, further research seems necessary to examine if oath taking phenomenon is influenced by the context of the communication. Similarly, exploration of whether age, gender, educational status, social class, personality, and religious orientation affect the application of swear words is another avenue for research. Still, investigation of different functions and purposes laid behind the application of swear words in Persian is a new line of research waiting for scholarly studies.

\section{Reference}

Abdel-Jawad, H, R. S. (2000). A Linguistic and Sociopragmatic and Cultural Study of Swearing in Arabic. Language, Culture and Curriculum, 13(2), 217-240. http://dx.doi.org/10.1080/07908310008666600

Gray, P. (1993) Oaths and language speech. Language \& Communication, 13(4), 311-325.

Jay, T. (2009). Do offensive words harm people? Psychology, Public Policy, and Law, 15(2), 81-101. http://dx.doi.org/10.1037/a0015646

Kiani. H. (1992). Oath in Persian language and literature. Tehran University publication: Tehran.

Lyona, D. T., \& Doradob J. S. (2008). Truth induction in young maltreated children: The effects of oath-taking and reassurance on true and false disclosures. Child Abuse \& Neglect, 32, 738-748. http://dx.doi.org/10.1016

Mansoury, A. (2011). The Relationship between Language and Social Capital in Ilam Kurdish: A Sociopragmatic Approach. Unpublished Master Thesis. Ilam University, Iran.

McEnery, A., \& Zhonghua, X. (2004). swearing in modern British English: the case of fuck 
in the BNC. Language \& Literature, 13(3), 235-268. http://dx.doi.org/10.1177/0963947004044873

Rassin, E. \& Muris, P. (2004). Why do women swear? An exploration of reasons for and perceived efficacy of swearing in Dutch female students. Personality and Individual Differences, 38, 166. http://dx.doi.org/10.1016

Simpson, J., Edmund, W. (2010). The Oxford English Dictionary. (2 Ed, 20). New York: Oxford University Press.

Stein-Wilkeshuis, M. (2002) Scandinavians swearing oaths in tenth-century Russia: Pagans and Christians. Journal of Medieval History, 28, 155-168. PII: S 0304 - 181(02)00003-9.

Strawson, G. (1986) Freedom and Belief. Oxford: Clarendon Press.

Taylor, B.A. (1975). Towards a structural and lexical analysis of 'Swearing' and the language of abuse in Australian English. Linguistics, 13, 17-43. http://dx.doi.org/10.1016/10.1515/

\section{Appendix}

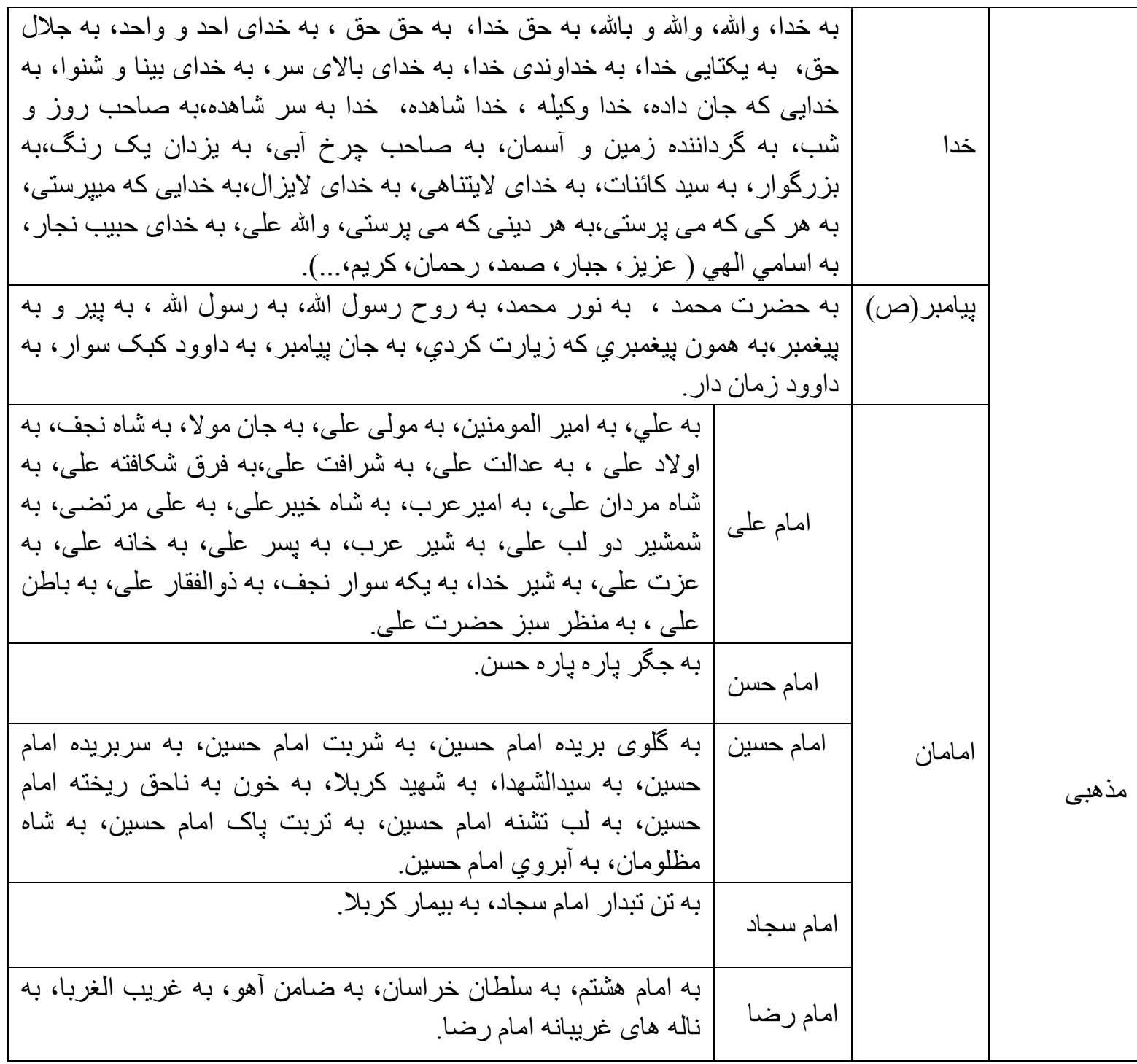




\begin{tabular}{|c|c|c|}
\hline | به حضرت مهدى، به امام زمان، به صاحب الزمان، به مهدي مو عود. & & \\
\hline 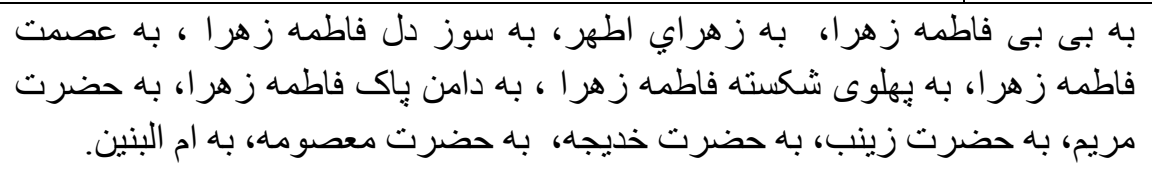 & زֶاكدامن & \\
\hline 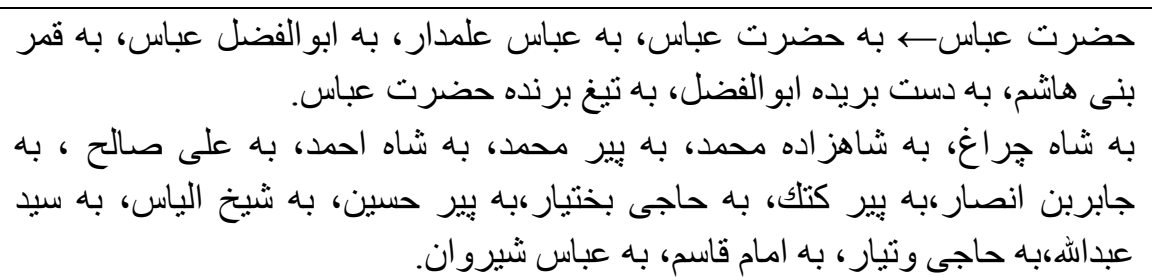 & امامز ادكان & \\
\hline 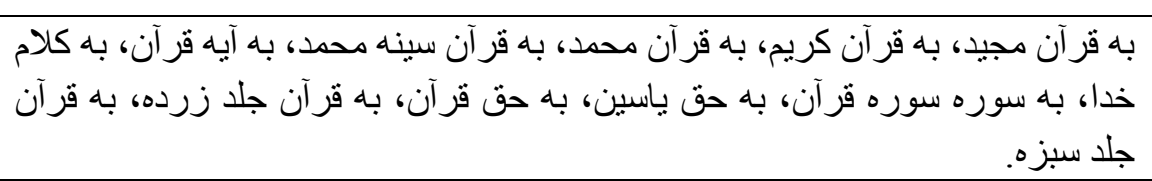 & قرآن & \\
\hline 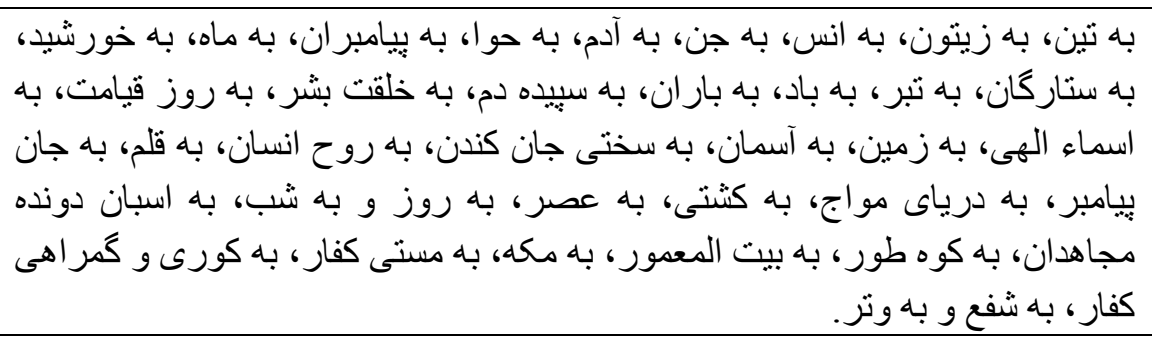 & قرجمهاى & \\
\hline ، به زمين قيامت، بـ شش كوشه قبر امام حسين، به دشت كربلا، به قتلكاه حسين، به خانه & 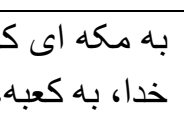 & مكان \\
\hline 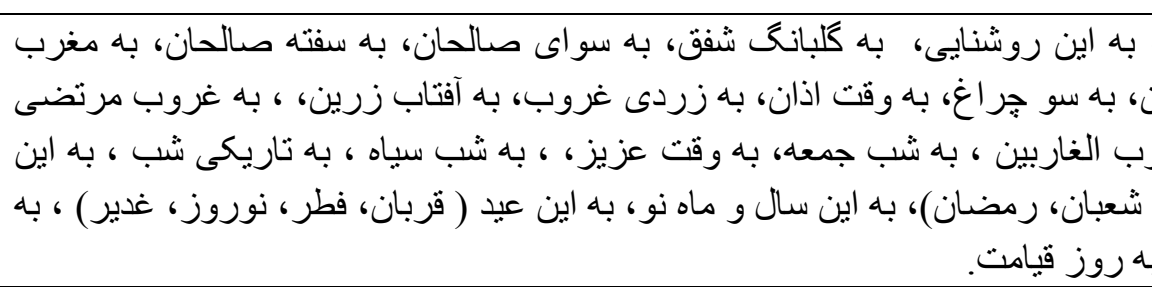 & 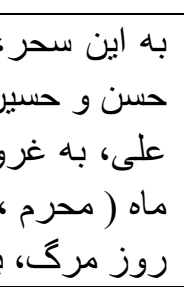 & زمان \\
\hline 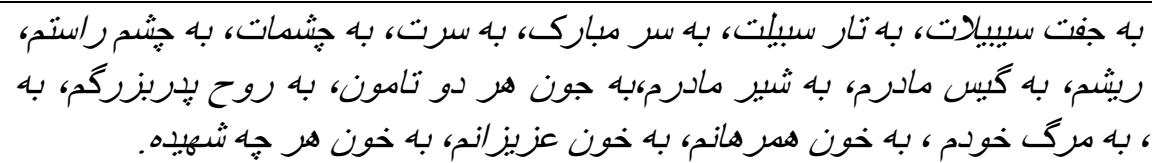 & 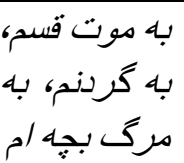 & 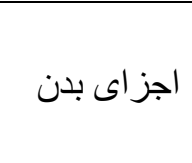 \\
\hline 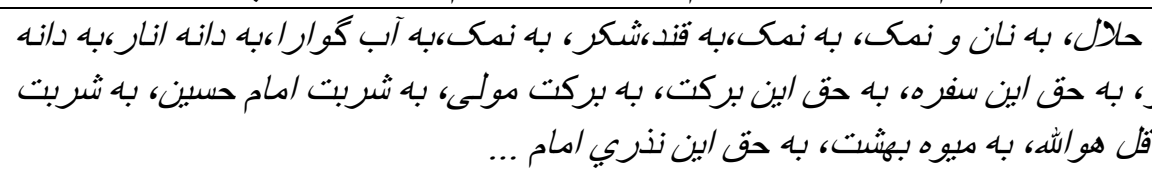 & 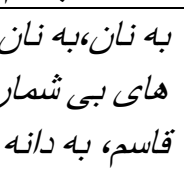 & غور اكى \\
\hline 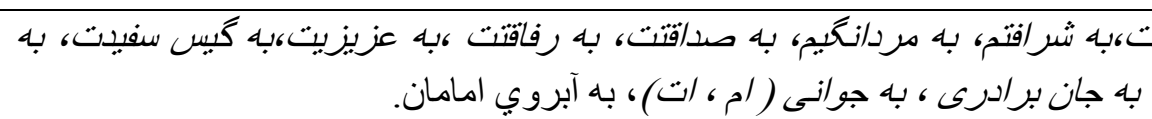 & ربيه قول درس & ارزشها \\
\hline 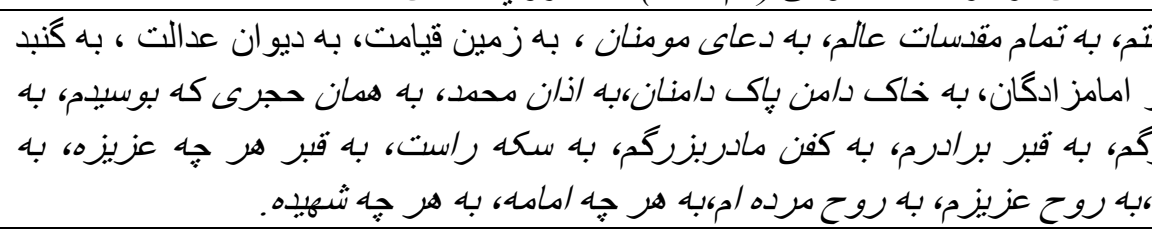 & 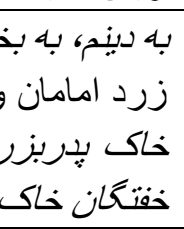 & مقدسات \\
\hline
\end{tabular}




\begin{tabular}{|c|c|}
\hline 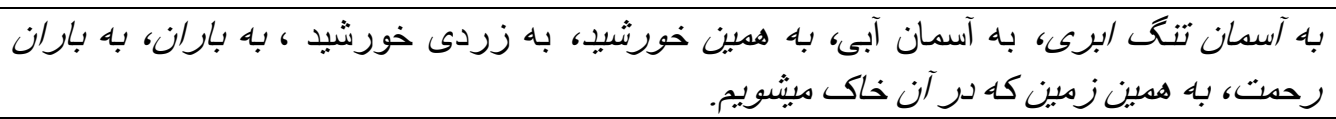 & مخلوقات \\
\hline 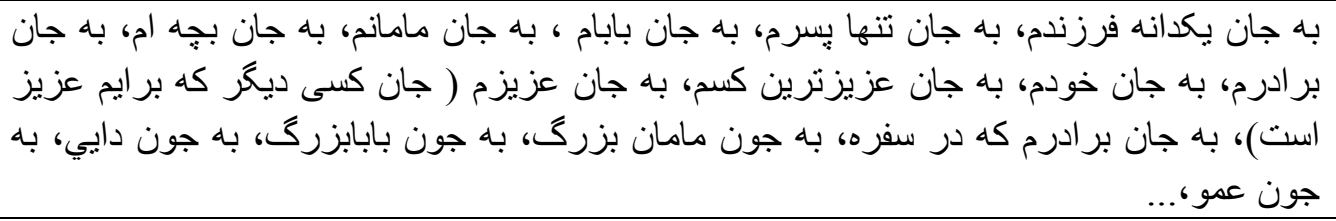 & خانو/ده \\
\hline 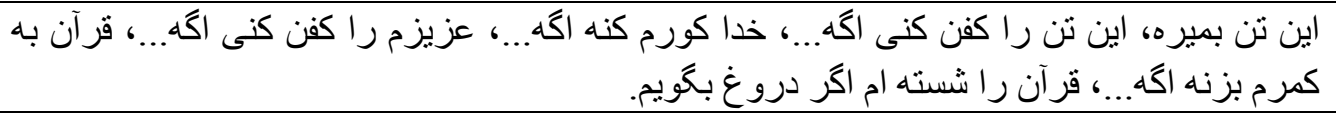 & 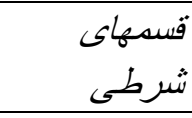 \\
\hline 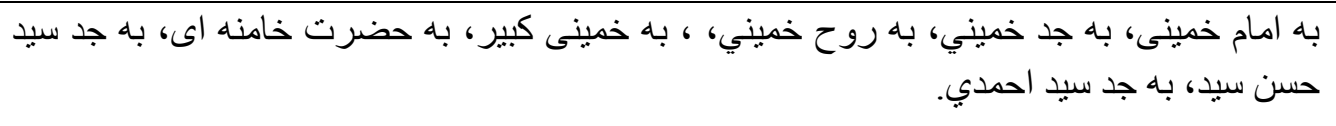 & اشخاص مهم \\
\hline
\end{tabular}

